\title{
Monika Piśniak*
}

\section{RYZYKO WYSTĘPUJĄCE W TRANSFERZE WIEDZY}

Zarys treści: Aktualnie za fundamentalny potencjał we współczesnej gospodarce uznaje się wiedzę, która stanowi źródło sukcesu bądź klęski ekonomicznej. Przedsiębiorstwa, w szczególności ich kierownictwa, muszą być zdolne do zapewnienia firmie zasobów pracowniczych gwarantujących najwyższy poziom wiedzy, kompetencji i umiejętności. Co za tym idzie w każdej organizacji powinien funkcjonować prawidłowo przebiegający proces transferu wiedzy, czyli taki, w którym zostaną zminimalizowane czynniki generujące ryzyko.

W przedłożonej publikacji, zostały zidentyfikowane na podstawie analizy literaturowej czynniki zakłócające prawidłowy proces transferu wiedzy, czyli występujące ryzyka.

Słowa kluczowe: Zarządzanie wiedzą, transfer wiedzy, ryzyko.

K 1 a s y fik a c j J E L: L 21; M 15

\section{WSTĘP}

Ze względu na wiele czynników (dynamika i turbulencja otoczenia itp.), głównym zadaniem przedsiębiorstwa staje się konieczność zdobywania wiedzy. Wiedzę tę przedsiębiorstwo powinno w coraz krótszym czasie przetwarzać, wykorzystując większą liczbę danych czy informacji. Wiedza, jaką dotychczas przedsiębiorstwo dysponuje czyli wiedza bazowa pozwala na asymilowanie i przyswajanie nowej wiedzy, warunkuje rodzaj i zakres pozyskiwanej wiedzy [Glabiszewski, 2014, s. 145]. Wiedza i informacja, ich jakość oraz aktualność stanowią zatem istotne czynniki konkurencyjności. Sukces w gospodarce w dzisiejszych czasach jest mierzony nie tylko udziałem firmy na rynku, ale również procesem zarządzania wiedzą oraz umiejętnością wykorzystania kapitału intelektualnego firmy [Grudzewski, Hejduk, 2004, s.133]. W większości procesów występujących $\mathrm{w}$ przedsiębiorstwie, jak również $\mathrm{w}$ procesie zarządzania transferem wiedzy występuje ryzyko. Aktualnie ryzyko staje się podstawową cechą zarządzania, powstaje przez to konieczność utrzymania go

* Adres do korespondencji: Monika Piśniak, Politechnika Częstochowska, Wydział Zarządzania, ul. Armii Krajowej 19b, 42-200 Częstochowa, e-mail: m.pisniak@wp.pl; 
w pewnych granicach, a to wymaga uwzględnienia ryzyka w procesie planowania zasobów oraz działań kompensacyjnych [Lichtarski, 2005, s.247].

Większość firm nie jest świadomych powiązań, jakie kreują oraz jak wygląda transfer wiedzy pomiędzy kooperantami, czy też komórkami tj. działami występującymi w przedsiębiorstwie. Dlatego liderzy, kadra kierownicza odgrywa kluczową rolę w procesie transferu wiedzy, to oni są odpowiedzialni za stworzenie optymalizującego własnego łańcucha wartości, który dodatkowo ułatwi wymianę informacji pomiędzy podmiotami, a w konsekwencji zlikwiduje bariery oraz wesprze transfer wiedzy, co umożliwi wydajniejszą realizację celów.

\section{TRANSFER WIEDZY}

Głównym tematem przedłożonej publikacji jest transfer wiedzy, który definiuje się, jako jeden $\mathrm{z}$ elementów zarządzania wiedzą. Jest to zbiór procesów, które pomagają tworzyć, upowszechniać i wykorzystywać wiedzę w celu skutecznej realizacji zadań, jakie ma na celu przedsiębiorstwo [Lichtarski, 2005, s.89].

$\mathrm{Na}$ wspomniany transfer składa się przepływ, absorpcja oraz modyfikacja wiedzy, które uzależnione są od specyfiki przedsiębiorstwa. Podstawowym elementem decydującym o przewadze konkurencyjnej przedsiębiorstwa jest dostarczenie wiedzy podmiotom, które jej potrzebują oraz dzielenie się nią w ramach powiązań, czyli jej transfer. Zatem skuteczny transfer wiedzy polega na jej przekazaniu, przyswojeniu, przetworzeniu, zrozumieniu oraz odpowiednim dopasowaniu do sytuacji zastosowaniu

Analizę transferu wiedzy należy zacząć od zdefiniowania zarządzania wiedzą, która ujęta w sposób ogólny polega na pozyskiwaniu odpowiednich środków, wypracowaniu i sterowaniu wykorzystaniem warunków, metod i technik umożliwiających przebieg procesów związanych z wiedzą.

W dostępnej literaturze można znaleźć wiele ujęć zadań operacyjnych zarządzania wiedzą, które najczęściej ujmowane są w formie procesu. Na przykład, A. Kowalczyk i B. Nogalski [2007, s. 87] przedstawiają w ramach cyklu megaprocesu wiedzy jej pozyskiwanie, rozwijanie, kodyfikację, transfer, wykorzystanie. Natomiast G. Probst w ramach systemu zarządzania wiedzą wyróżnia następujące podstawowe zadania z punktu widzenia poziomu operacyjnego: identyfikowanie, zdobywanie, rozwijanie, dystrybucję i dzielenie się doświadczeniami, wykorzystanie, zachowywanie wiedzy [Leibold, Probst, Gibbert 2002, s. 190-191].

Do procesu transferu wiedzy można różnie podchodzić, jest to uzależnione od sposobu rozumienia wiedzy czy też rozpatrywanego typu wiedzy. Jeśli zostanie przykładowo przyjęte, że wiedza jest pozostałością 
myślenia, a dokładniej jest efektem zastosowania informacji oraz doświadczeń w procesie myślenia [McDermott,1999,s.106], wtedy wiedza staje się ściśle powiązana z umysłem człowieka. W tej sytuacji to nie wiedza jest transferowana ale informacja, która następnie zostaje przekształcana $\mathrm{w}$ wiedzę w procesie myślowym.

Z umysłem człowieka wiedzę łączą Japończycy przyjmując, że jest nią potwierdzone przekonanie. Wiedza dotyczy przekonań oraz oczekiwań, jest funkcją szczegółowego nastawienia, perspektywy jak również intencji oraz działań. Jest względna i uzależniona od kontekstu. Natomiast informacja ujmowana jest, jako strumienie wiadomości, które są instrumentami odkrywania i budowania wiedzy [Nonaka, Takeuchi 2000, s. 80-81]. Informacja przekształca się w wiedzę kiedy w procesie interpretacji daje kontekst oraz utożsamia się w wierzeniach i zaangażowaniu człowieka [Nonaka, Toyama, Konno 2000, s. 7]. W tym ujęcia w procesie transferu wiedzy informacja jest nośnikiem wiedzy.

W przypadku koncepcji zachodnich wiedza wiązana jest $\mathrm{z}$ danymi oraz informacjami. Na przykład G. Probst, S. Raub i K. Romhardt [2002, s. 27] twierdzą, że pojedyncze znaki, zestawione zgodnie z regułami określonej składni tworzą dane. Natomiast dane, zinterpretowane w konkretnym kontekście dostarczają informacji. A dalej informacje, którym zostanie nadana struktura, mogą być wykorzystane w pewnym obszarze działalności i dopiero wtedy zyskują miano wiedzy (rys. 1). Jednocześnie autorzy ci zakładają, że przyswajanie wiedzy czy też posiadane umiejętności gromadzenia i interpretowania przez ludzi dużej ilości informacji wymagają czasu i dlatego transformacja danych następuje w informacje, a następnie dopiero w wiedzę. Proces ten jest procesem ciągłym. W omawianym ujęciu informacja jest elementem wiedzy oraz związana jest bezpośrednio z umysłem człowieka, gdyż powstaje przez myślową interpretację kontekstowo osadzonych danych. Transfer wiedzy dokonywany jest poprzez przesyłanie danych, które są elementem wiedzy.

Rys. 1. Relacje w hierarchii pojęć dane, informacje a wiedza

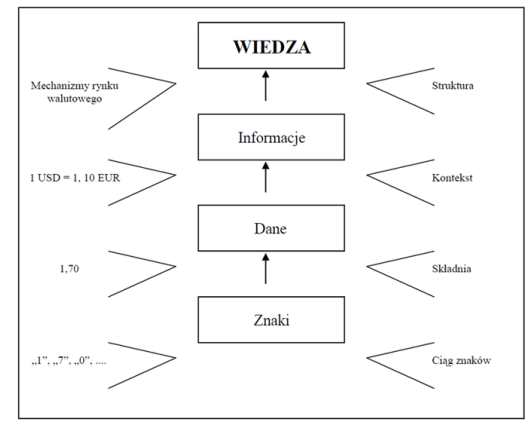

Źródło: [Probst, Raub, Romhardt 2002, s. 27]. 
Przedstawione sposoby rozumienia wiedzy oraz jej powiązań z informacją dotyczą wiedzy spersonalizowanej postaci jawnej i wskazują na drobne niuanse, które z kolei z punktu widzenia procesu transferu wiedzy, są w niektórych sytuacjach, bardzo istotne. Można wyprowadzić na ich podstawie pewne uogólnienie oraz wniosek, że ten wiedza przekazywana jest między ludźmi w procesach informacyjno-komunikacyjnych. Jeśli chodzi o wiedzę ukrytą, to nie jest ona komunikowalna, ale człowiek jest ją w stanie zdobyć poprzez zdobywanie praktycznych doświadczeń (np. podczas nauki zawodu). Natomiast wiedza jawna może być zapisywana na różnych nośnikach, np. elektronicznych, która przyjmuje w ten sposób postać skodyfikowaną. Wówczas jej transfer między ludźmi może być dokonywany przy użyciu sieci komputerowych lub innych metod przesyłu informacji, jak też nawet w klasyczny sposób poprzez transport dokumentów, książek, projektów stworzonych w formie papierowej.

\section{POJĘCIE RYZYKA}

Pojęcie ryzyka oraz jego definiowanie budzi kontrowersje, ze względu na wiązanie tego zjawiska z negatywnymi konsekwencjami. Słowo „ryzyko” pochodzi z łacińskiego słowa „riscare”, które oznacza „odważyć się”, nadając przez to kluczowe znaczenie ryzyka, jako kwestii wyboru, a nie przeznaczenia [Bernstein 1997, s.19].

Współczesny słownik języka polskiego definiuje ryzyko, jako: „możliwość sukcesu, ale także niepowodzenia, porażki, straty. To także przedsięwzięcie, którego wynik jest niepewny, wątpliwy. Ryzyko to również możliwość powstania szkody"[Dunaj 1998, s.598].

Uzupełnieniem definicji podanej przez słownik języka polskiego jest opis pochodzący z Encyklopedii organizacji i zarządzania, mówiący, że wielkość ryzyka jest zdeterminowana poprzez: typ, zakres, a także warunki, w jakich proces przebiega [Pasieczny 1981, s.410].

Biorąc pod uwagę istotność problemów związanych z najlepszym wyborem możliwości zmierzenia poziomu ryzyka, należy zagłębić się w dostępne definicje tego zjawiska. Wśród definicji dostępnych w literaturze można zauważyć trzy główne grupy, według których można je podzielić [Piśniak 2015, s.136-140]:

- Ryzyko traktowane, jako pojęcie niemierzalne. Do tej grupy można zaliczyć najwięcej dostępnych w literaturze definicji. Dotyczą one sfery psychologicznej, filozoficznej oraz ekonomicznej, nieposiadające elementów operacyjności.

- Ryzyko traktowane, jako pojęcie mierzalne w sensie intuicyjnym (bez wskazania odpowiedniego sposobu pomiaru). W tej grupie znajdują się definicje, w których występuje wskazanie na mierzalność ryzyka, jednak ich autorzy 
nie potrafią wskazać najlepszego miernika.

- Ryzyko oparte o kryteria mierzalności - mierzalność empiryczna. Do tej grupy należą autorzy definicji, którzy wprowadzili element pomiaru. Można zauważyć, że występują typowe mierniki, takie jak prawdopodobieństwo, albo jego synonimy (hazard). Jak również miary typu odchylenie standardowe.

- Ryzyko mierzone matematycznie, probabilistycznie.

- Ryzyko mierzone statystycznie.

Ponieważ stanem wywołującym ryzyko jest niepewność, przytoczenie jej definicji jest jak najbardziej zasadne: „Niepewność to brak zdecydowania, pewności i wiary w siebie, to brak poczucia bezpieczeństwa i ufności w pomyślną przyszłość. To także niepokój towarzyszący oczekiwaniu na jakąś ważną decyzję, rozstrzygnięcie czegoś” [Dunaj , 1998, s. 283].

Pojęcie niepewności poprawnie łączone jest z ryzykiem, nie należy jednak niebezpieczeństwa z nim łączyć, ponieważ ryzyko różni się od niebezpieczeństwa podstawową kwestią, niebezpieczeństwo jest związane $\mathrm{z}$ zupełnie pewną stratą, a to już nie jest ryzykiem [Kaczmarek, 2008, s. 52-53].

Analizując te dwie definicje ściśle powiązane ze sobą, można zauważyć jak wielki wpływ na ryzyko ma stan niepewności.

Poniższy schemat doskonale obrazuje opisaną zależność pomiędzy ryzykiem a stanem niepewności.

Rys.2. Zależność pomiędzy ryzykiem, niepewnością a decyzją.

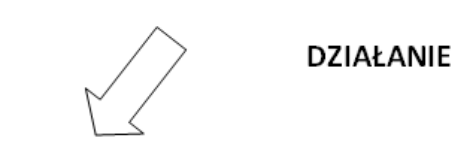

NARZUCA

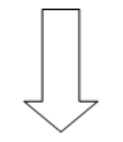

DECYZJĘ

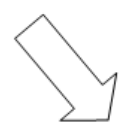

NIEPEWNOŚĆ

DOPROWADZA DO

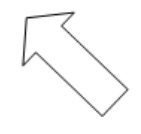

WYMUSZA

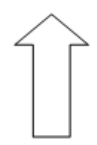

RYZYKO

Źródło: opracowanie własne

Niepewność jest warunkiem zarówno koniecznym jak i wystarczającym, aby wystąpiło ryzyko. Dlatego też ryzyko powinno być utożsamiane z wolnym wyborem, a nie traktowane, jako przeznaczenie [Staniec, Zawiłła-Niedźwiedzki, 2008, s.14-15]. Jeśli następuję stan niepewności, pojawia się cykl zamknięty 
występujących po sobie zależności. Kiedy podejmowana jest decyzja, powstaje ryzyko, idąc dalej ryzyko wywołuje działanie, które z kolei znowu wymusza podjęcie kolejnych decyzji [Staniec, Zawiłła-Niedźwiedzki, 2008, s.14-15].

\section{RYZYKA WYSTĘPUJĄCE W TRANSFERZE WIEDZY}

Badanie zjawisk ekonomicznych, w których przebieg ma charakter losowy, sprawia, że opis sytuacji, czyli rozkład prawdopodobieństwa jest możliwy dopiero w momencie, kiedy badane zjawisko występuje. Przyjmując za niepodważalny fakt, że w większości otaczające nas zjawiska rzeczywiste mają naturę probabilistyczną, należy pamiętać o uwzględnieniu ryzyka w transferze wiedzy.

Zaczynając analizę występujących ryzyk w transferze wiedzy, należy zacząć od tych, które związane są z omawianym procesem tj. ryzyko związane z kodowaniem informacji, ryzyko zniekształcenia informacji, ryzyko opóźnienia dostarczenia informacji, ryzyko związanego z odbiorem informacji i jej modyfikacją. Wymienione powyżej rodzaje ryzyka są związane ściśle z przepływem wiedzy w przedsiębiorstwie.

Aby zminimalizować czynniki generujące wyżej wymienione ryzyka, należy: zapewnić kompleksowość przekazywanej wiedzy, pamiętać o zamianie aktywów intelektualnych organizacji w wynik ekonomiczny, wspierać przywództwo, kulturę organizacyjną, technologię i system pomiarowy, łączyć ze sobą ludzi, przede wszystkim tych, którzy posiadają wiedzę z tymi, którzy jej potrzebują, stworzyć hybrydowe połączenie ludzi i technologii [Grudzewski, Hejduk, 2004, s.95].

Kolejnym elementem generującym ryzyko jest trudność w przekazywaniu wiedzy, niechęć do dzielenia się wiedzą. Główne czynniki według autorki to między innymi:

- strach przed utratą pracy, ponieważ wiedza pracownika jest bezcenna dopóki się nią nie podzieli;

- strach przed przekazywaniem swoich pomysłów. Zdecydowanie lepiej dla pracownika unikać niepotrzebnych utrudnień, czy też brak pewności, co do przydatności swoich pomysłów;

- strach przed zmianami, ponieważ komfortowa sytuacja dla pracowników jest, jeśli nic nie pozostaje zmienione itd. [Grudzewski, Hejduk, 2004, s.126-127].

Wszystkie wymienione powyżej czynniki i wiele innych wynikających z powyższych, związanych jest $\mathrm{z}$ kulturą organizacyjną $\mathrm{w}$ danym przedsiębiorstwie, wynika $\mathrm{z}$ tego jak ważne są systemy motywujące dla zatrudnionych i dbałość o wartościowych pracowników. 
Uzupełnieniem poprzednich determinant ryzyka w procesie transferu wiedzy są czynniki powodujące niechęć do upowszechniania wiedzy. Do nich należą:

- obcy język przedsiębiorstwa współpracującego,

- utrata pozycji na rynku,

- dokładność wiedzy,

- duże odległości itd. [Grudzewski, Hejduk, 2004, s.126].

Czynniki te, powodują poczucie niepewności, co utrudnia upowszechnianie wiedzy, ponieważ organizacja nie wie, czy postępuje właściwie otwierając się na inne firmy.

Następnym ryzykiem występującym w transferze wiedzy jest ryzyko związane z systemami informacyjnymi tzn. ryzyko niewłaściwego działania systemu, ryzyko przestoju, co w konsekwencji opóźni dostarczenie informacji, czy ryzyko niepowodzenia $\mathrm{w}$ przesyle wiedzy. Z systemami informacyjnymi wiążę się jeszcze jedno ryzyko, a mianowicie związane z przekroczeniem zakładanych wydatków [Zygała, 2007, s.54].

Systemy informacyjne generują jeszcze jedno ryzyko, związane $\mathrm{z}$ bezpieczeństwem informacji. Polityka bezpieczeństwa informacji powinna zdefiniować strategie analizy ryzyka. Dlatego oprócz podstawowej ochrony danych, należy przeprowadzić analizę ryzyka i określić, jakiej ochrony potrzeba, aby zastosować metodę kombinowaną, czyli nie tylko podstawową, jeśli takie wyniki otrzyma przedsiębiorstwo po przeprowadzonej analizie [Kiełtyka, 2003, s.234-235].

\section{PODSUMOWANIE}

Transfer wiedzy jest głównym procesem z udziałem wiedzy, bez którego nie byłoby możliwe zgromadzenie przez człowieka wiedzy, jej łączenie z posiadanymi zbiorami i poddanie dalszej kreacji, zapisanie czy stosowanie w działaniu. Transfer wiedzy stanowi przez to podstawę realizacji procesu uczenia się organizacji oraz stanowi składnik wielu strategii wykorzystywanych w ramach zarządzania wiedzą.

Aby proces transferu wiedzy przebiegał poprawnie należy przeprowadzić identyfikację czynników generujących ryzyko w danym przedsiębiorstwie, następnie należy starać się usunąć poprzez odpowiednie zabezpieczenia tj. systemy informacyjne do przesyłania danych oraz zadbać o kulturę organizacyjną w organizacji. 


\title{
LITERATURA
}

Glabiszewski W., (2014), Potencjat absorpcyjny w świadomości naczelnego kierownictwa banków, AUNC Zarządzanie nr 2.

Grudzewski W.M., Hejduk I.K. (2004), Zarządzanie wiedza w przedsiębiorstwach, Difin, Warszawa.

Lichtarski J. (red.) (2005), Podstawy nauki o przedsiębiorstwie, Wydawnictwo Akademii Ekonomicznej im. Oskara Langego we Wrocławiu.

Bernstein P.L. (1979), Przeciw bogom. Niezwykłe dzieje ryzyka, WIG-Press, Warszawa.

Piśniak M. (2015), Taksonomia definicji ryzyka i próba ich klasyfikacji, Ekonomiczne i prawne wyzwania roku 2015, Lwów.

Dunaj B. (red.) (1998), Słownik współczesnego języka polskiego, Wilga, Warszawa.

Pasieczny L. (red.) (1981), Encyklopedia organizacji i zarządzania, PWE, Warszawa.

Nonaka, I.; Toyama, R.; Konno, N. (2000): SECI, Ba and Leadership: A unified model of

dynamic knowledge creation, Long Range Planning, Vol. 33.

Kowalczyk A., Nogalski B. (2007), Zarządzanie wiedzą. Koncepcja i narzędzia, Difin, Warszawa.

Nonaka I., Takeuchi H., Kreowanie wiedzy w organizacji, Poltext, Warszawa 2000

McDermott R. (1999), Why Information Technology Inspired but cannot deliver knowledge management, California.

Gibbert M., Leibold M., Probst G. (2002), Five styles of customer knowledge management, and how smart companies use them to create value, Publicis Kommunikations Agentur Gmbh, GWA, Erlangen.

Probst G., Raub S., Romhardt K. (2002), Zarzadzanie wiedza w organizacji, Oficyna Ekonomiczna, Kraków.

Zygała R.(2007), Podstawy zarzadzania informacja w przedsiębiorstwie, Wydawnictwo Akademii Ekonomicznej im. Oskara Langego we Wrocławiu, Wrcoław.

Kiełtyka L.(2003), Ochrona i bezpieczeństwo informacji w przedsiębiorstwie, Kantor Wydawniczy Zakamycze.

Kaczmarek T.T. (2008), Ryzyko i zarządzanie ryzykiem ujęcie interdyscyplinarne, Warszawa Difin.

Staniec I., Zawiła-Niedźwiecki J. (2008), Zarządzanie ryzykiem operacyjnym, C.H. Beck Warszawa.

\section{THE RISKS OF KNOWLEDGE TRANSFER}

\begin{abstract}
Currently, as a fundamental potential in the modern economy is considered to knowledge, which becomes a source of economic success or defeat. Enterprises, in particular, their management must be able to provide the company staff resources to guarantee the highest level of knowledge, competencies and skills. Hence in any organization should function properly extends the knowledge transfer process, which is one in which will be minimized factors generating the risk.

The submitted publications were identified based on the analysis of literature confounders proper knowledge transfer process, which is occurring risks.
\end{abstract}

Keywords: Knowledge management, knowledge transfer, risk. 